way to accomplish this would be for each of us to bring one young trainee or junior faculty member with us to the meeting each year at no expense to them. Chairs of departments of medicine might also develop programs to sponsor attendance at the meeting of faculty not yet elected to membership. I believe that the experience of interacting with members at the meeting, and being a part of this gathering of some of the best and most important people in academic medicine, would do much to encourage their aspiration to become a part of this scene. It would also introduce them to the network of more senior figures who can help to advise them and shape their careers in the future. It is, after all, through such collective mentoring and intergenerational interaction that we can best pass along the very rich traditions as well as the values of scientific medicine to which so many of us have dedicated our careers.
Address correspondence to: Robert Lefkowitz, Howard Hughes Medical Institute, Departments of Medicine and Biochemistry, Room 468, Carl Building, Research Drive, Box 3821, Duke University Medical Center, Durham, North Carolina 27710, USA. Phone: (919) 684-3755; Fax: (919) 684-8875; E-mail: lefko001@receptor-biol.duke.edu.

1. Smith, L.H., Jr. 2008. Homage to Atlantic City. J. Clin. Invest. 118:1224-1227.

2. Williams, L.T., and Lefkowitz, R.J. 1976. Alpha-adrenergic receptor identification by $(3 \mathrm{H})$ dihydroergocryptine binding. Science. 192:791-793.

3. Frankfurt, H.G., 1986. On bullshit. Raritan. 6:81-100.

4. Frankfurt, H.G. 2005. On bullshit. Princeton University Press. Princeton, New Jersey, USA. 80 pp.

5. Goldstein, J.L. 1986. On the origin and prevention of PAIDS (paralyzed academic investigator's disease syndrome). J. Clin. Invest. 78:848-854.

6. Lefkowitz, R.J. 1988. The spirit of science. Presidential address to the American Society for Clinical Investigation, Washington, DC, 30 April 1988. J. Clin. Invest. 82:375-378.

\title{
The physician-scientist: a value proposition
}

\author{
Elizabeth G. Nabel
}

National Heart, Lung, and Blood Institute, NIH, Bethesda, Maryland, USA.

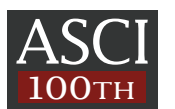

\begin{abstract}
The American Society for Clinical Investigation has supported the career development of physicianscientists for the past 100 years. As the ASCI looks to its next 100 years, it must be a leading force, not only for advancing the research of physician-scientists, but also for stimulating public advocacy for biomedical research in this country.
\end{abstract}

When my husband Gary and I left the safe haven of our postdoctoral fellowships at the Whitehead Institute and Brigham and Women's Hospital, respectively, to join the faculty at the University of Michigan in 1987, we entered uncertain territory, lured by strong recruiting. The welcome that embraced us there - an inspiring academic environment and supportive mentors - made all the difference. Bill Kelley, chair of the Department of Internal Medicine, was energetically building outstanding academic programs. I joined a cardiac catheterization lab with colleagues Bill O'Neill, Eric Topol, Steve Ellis, and Eric Bates; Gary joined a nascent Howard Hughes Medical Institute unit including David Ginsburg, Francis Collins, Jeff Leiden, Craig Thompson, John Lowe, and Andy Feinberg. Bill set his young faculty free to pursue their research ideas, and sparks erupted. We were in our mid- to late 30 s, energetic and creative, and we fed off each others' vitality. It was a period of extraordinary productivity. Bill understood the value of fostering an engaging, intellectually vibrant academic culture, standing back to let us pursue our creative interests but stepping in when we needed support or resources.

I benefited tremendously, personally and professionally, from this academically enriching environment and Bill's support. My initial job was as an interventional cardiologist. Angioplasty treatment of focal coronary artery lesions, in combination with thrombolytic therapies, was on the rise. However, we saw substantial numbers of our patients return to the clinic with restenoses. Cardiologists addressed the clinical problem with mechanical interventions aimed at shaving off the atheromatous lesion by atherectomy, rotor blades, and early metallic stents. I didn't think that the solution lay solely in the domain of mechanical devices; rather, I believed that cura-

Conflict of interest: The author has declared that no conflict of interest exists. Citation for this article: J. Clin. Invest. 118:1233-1235 (2008). doi:10.1172/JCI35074. tive interventions would have to be based on an understanding of the molecular and cellular biology of the restenosis process - and I was determined to advance that understanding. I approached Bill in 1988 with a request to initiate a pilot basic research project to understand the growth regulation of endothelial and vascular smooth muscle cells within restenotic lesions, using molecular approaches including gene transfer. Bill provided \$50,000 a year for two years (a lot of money in the late 1980s) and promised me space if I could obtain NIH funding. With the start-up funds, I conducted a series of experiments, piloting the techniques and methods for transfer of recombinant genes into blood vessels in situ, for which NIH R01 funding followed in $1989(1,2)$.

The values embodied in my first academic environment are precisely those articulated by the ASCI. We elect young members for their outstanding scholarly achievements in biomedical research. We are dedicated - individually and as a professional society - to advancing human health through our work at the bench, the bedside, and the blackboard. And just as we all have benefited from mentoring, we in turn commit ourselves to mentoring the next generation of physician-scientists. My experience in Michigan taught me that innovation, creativity, and, above all, striving for excellence must be the major drivers; the ASCI embodies and articulates those same values.

I was deeply honored to be elected to the ASCI in 1993, but to be honest, I have no memory of attending my first meeting. Somehow, I had more immediate concerns on my plate. My focus at the time was twofold - conducting experiments and publishing my research results; and, with Gary, raising our three children, who were then ages 7,5 , and 1 . I suspect that the often-competing demands of my research and family were similar to challenges faced by other young mothers who were developing their careers at academic health centers and probably no different from the bal- 
ancing act that women struggle with today. It was hard, although I didn't want to admit it at the time. The difficult reality for women who aspire to have successful academic careers and families is the painful convergence of time clocks: the point when we have completed training and finally are able to have children without serious impediments to residency and fellowship schedules is precisely the point when tenure requirements and election to honor societies like the ASCI hold sway. Does it really need to be so hard for young women? Are we creating unnecessary circumstances that deter women from pursuing academic careers or elbow them off the academic career ladder once they've begun the pursuit?

I returned to the ASCI through leadership positions in midcareer, when I had more time to devote to the Society's activities. I had the privilege of serving as a councilor and secretary to the ASCI Council, and I was fortunate indeed to be asked by Steve Weiss to join the editorial board of the JCI as an associate editor during its Michigan tenure. The camaraderie was spectacular and invigorating. We discussed science, proposed and debated ideas, and thoroughly enjoyed one another's company. We lived in the spirit of ASCI ideals.

For many, election to the ASCI has been a badge of honor; yet I would argue that if ASCI members see their role in the Society as purely honorific, they are abdicating their responsibilities to the larger academic medicine community and forgoing opportunities to influence the biomedical research agenda. The ASCI can and must be a leading force, not only for advancing the research of physician-scientists but also for stimulating public advocacy for biomedical research in this country. ASCI members must assume leadership roles in all domains of biomedical research, be they at academic health centers, in the pharmaceutical and biotechnology industries, in government agencies, or in nongovernment organizations. To this end, I would propose several key issues that merit a national dialogue by the ASCI leadership and its members.

Communicating the benefits of biomedical research. The NIH's \$29.1 billion budget for fiscal year (FY) 2008 is essentially the same as it was in FY 2007 (3), and its real purchasing power is eroded by inflationary increases in the costs of personnel, equipment, and supplies. In fact, annual NIH budget increases have not kept up with inflation since the budget doubling was completed in FY 2003 (4). And there is no significant relief on the horizon. At the $\mathrm{NIH}$, we have redirected priorities to maximize funding of investigator-initiated research project grants by keeping administrative costs, the intramural program, and infrastructure expenses well below inflation. However, as the budget remains flat and inflation continues to nibble at purchasing power, it has become apparent that strategic priority setting and careful management of funds are not sufficient to satisfy the demand for grant funding. Why has the nation's commitment to science fallen short in recent years? Clearly, larger forces have prevailed, as biomedical research is increasingly being forced to compete against other domestic priorities. Now more than ever is the time for physician-scientists to let their voices be heard with respect to the importance of basic discovery, clinical research, and population studies to the health and well-being of Americans.

Career development of new investigators. The ASCI historically has been a home for physician-scientists, particularly early in their careers. Erosion of biomedical research funding adds an untenable element of uncertainty to the career paths of many young investigators. This is a crisis that we must join forces to address. As the director of the National Heart, Lung, and Blood Institute (NHLBI),
I have been strongly committed to the training and career development of new investigators, and I am proud of the innovative steps the institute has taken to advance this goal (5). The NHLBI is also an enthusiastic supporter of the NIH's new Pathway to Independence awards, designed to retain promising scientists and give them the opportunity for independent research at an earlier stage in their careers (http://grants.nih.gov/grants/guide/pa-files/PA06-133.html). The ASCI has taken a number of steps to support physician-scientists at critical career junctions. These laudable efforts can and should be expanded, in partnership with the NIH, and reinforced by local university policies and programs.

Health care reform. Health care costs are far higher in the United States than in any other developed country, whether measured in per capita expenditures or as a percentage of the gross domestic product $(6,7)$, and they continue to increase at an alarming rate. This is the worst long-term fiscal crisis facing the nation, and it demands a solution, but finding one will be neither easy nor palatable. Why should the ASCI have a stake in this discussion? Simply put, advances in biomedical research drive improvements in patient care and - arguably even more important - in disease prevention. Understanding the interdependency between the nation's health care and its research enterprise is critical, not just for physicians but for policymakers and the public. The "consumer-directed health care" movement calls for providing people with enough understanding about doctors and treatments to make wise decisions. I believe that information about medical research advances in fields such as genetics and stem cell biology must be integral to the package we provide consumers. Explaining complex scientific concepts and research findings in understandable language is not easy, but who is in a better position to do so than physician-scientists and the ASCI leadership?

Globalization of biomedical research and research training. Scientific discovery knows no boundaries. We seek to do the best science with the best scientists, regardless of geographic location. Recently the concept of medical diplomacy - "winning the hearts and minds of people in poor countries by exporting medical care, expertise and personnel to help those who need it most" (8) - has emerged and has been embraced by political leaders around the globe. Equally apt is the concept of scientific diplomacy, that is, the goodwill that accrues from scientific collaborations and exchanges with colleagues worldwide. Many of us have had such collaborations throughout our careers, perhaps not fully recognizing the privilege we enjoyed as scientists to form these professional relationships. As the globalization of scientific discovery and health care accelerates over the next decade, I believe there is a unique opportunity for the ASCI to be a worldwide leader in training physician-scientists, fostering collaborations among young investigators, and facilitating scientific exchanges through international meetings and forums.

The challenges facing physician-scientists are significant. The ASCI must exert inspired leadership to encourage the brightest and the best to pursue careers in biomedical research; to further their career development, particularly during the rough early years; to embrace and tackle head-on the difficult policy issues; and to be a force for transforming biomedical research worldwide. Change is never easy and rarely smooth. But to sit back and rest on our laurels is not an option if we want our profession reach its full potential in the global society. The opportunities are too great for us to forsake. Strong ASCI leadership and active engagement of ASCI members will indeed make it possible to 
achieve these goals. Physician-scientists are too valuable to this society not to do otherwise.

Address correspondence to: Elizabeth G. Nabel, National Heart, Lung, and Blood Institute, NIH, Building 31/Room 5A48, Bethesda, Maryland 20892, USA. Phone: (301) 496-5166; Fax: (301) 402-0818; E-mail: nabele@nih.gov.

1. Nabel, E.G., et al. 1989. Recombinant gene expression in vivo within endothelial cells of the arterial wall. Science. 244:1342-1344.

2. Nabel, E.G., Plautz, G., and Nabel, G.J. 1990. Site-specific gene expression in vivo by direct gene transfer into the arterial wall. Science. 249:1285-1288.
3. Mervis, J. 2008. Promising year ends badly after fiscal showdown squeezes science. Science. 319:18-19.

4. Zerhouni, E.A. 2006. NIH in the post-doubling era: realities and strategies. Science. 314:1088-1090.

5. Nabel, E.G. 2005. Notes from the Director, National Heart, Lung, and Blood Institute: fostering the independence of new investigators. Circulation. 112:2217-2218.

6. 2007 November 25. The high cost of health care [editorial]. The New York Times. http://www.nytimes.com/2007/11/25/opinion/25sun1.html?ex=1353733200\& en=fd759b7bd19ebf24\&ei=5124\&partner=permalink\&exprod=permalink.

7. Pear, R. 2008 January 8. Health spending exceeded record $\$ 2$ trillion in 2006. The New York Times. http://www.nytimes.com/2008/01/08/us/08health.html?ex= $1357621200 \&$ en $=17$ ece $401566658 \mathrm{ca} \& \mathrm{ei}=5124 \&$ partner $=$ permalink\&exprod $=$ permalink.

8. Fauci, A.S. 2007. The expanding global health agenda: a welcome development. Nat. Med. 13:1169-1171.

\section{Atlantic City is passé — l'm betting on Chicago}

\section{Jonathan Epstein}

Department of Cell and Developmental Biology, Institute for Regenerative Medicine, and Cardiovascular Institute, University of Pennsylvania, Philadelphia, Pennsylvania, USA

My first ASCI meeting as a member was in Chicago in 2001. I was absolutely thrilled to have been elected and eager to attend. I presented a poster on neural crest contribution to the cardiovascular system, and I arrived at the poster session a few minutes late. I was shocked to find Dan Foster, Joe Goldstein, and Michael Brown examining my data. They were pointing at figures and arguing about some point or other. My first reaction was to turn away and to disappear into the crowd. I summoned my courage, however, and introduced myself. Without further formality, I was subjected to a withering dual-barreled barrage of skepticism and inquiry from Goldstein and Brown. I had supposed that their interests were limited to cholesterol and lipid metabolism, and I was surprised at their interest in my work and detailed knowledge of the field. I couldn't believe that I was engaged in data analysis with Goldstein and Brown - and it was my data! Eventually, Bill Kelley arrived. He had recruited me to Penn five years earlier, and he casually (but loudly) commented to Dan Foster that Goldstein and Brown were "taking a little too much interest" in my work.

They were all, of course, operating with ulterior motives. R. Sanders (Sandy) Williams had recently stepped down as chief of Cardiology at UT Southwestern to become dean at Duke. Within a few months, I was visiting Dallas to interview for his prior position, and Goldstein and Brown welcomed me to town. It happened to be September 11, 2001, and I had dinner with Don Seldin and Dan Foster that night in Dallas as we all digested the change that the world had undergone that day.

The UT Southwestern offer was not the only opportunity for me that began because of a connection or a conversation at the ASCI meetings. While most of us no longer present our first abstract or finest unpublished data at the combined meetings, they remain

Conflict of interest: The author has declared that no conflict of interest exists. Citation for this article: J. Clin. Invest. 118:1235-1236 (2008). doi:10.1172/JCI35039. the most concentrated focus of academic leadership available to the up-and-coming physician-scientist. At every turn, I have found myself rubbing elbows with those I had only read about, or heard about, during my training. As a place to seek advice or inspiration - or a job - these meetings remain unsurpassed.

I have attended the meetings each year since 2001. There is uniqueness and purpose to these meetings that goes beyond networking and reuniting with old friends. The yearly gathering helps me to appreciate the fascination and inquisitiveness that all members share. I am frequently struck by the common threads that unite research areas, which have grown so subspecialized and independent that we often fail to even hear about the latest results outside of our field until we read about them in the lay press. The meetings never fail to leave me once more impressed with the importance and potential of the well-rounded physician-scientist. I cannot think of another conference or event that takes its place in this regard. Although new primary data are now only rarely presented at the oral sessions (though the ASCI Council is changing that), a review of the past three years' agendas reveals an astounding compendium of scientific advance and excellence (Table 1): six Nobel laureates, four Lasker awardees, seventeen members of the National Academy of Sciences, nineteen members of the Institute of Medicine, and a broad range of discovery to inspire the next generation.

The giants remind us that the Tri-Societies meetings were once able to assemble nearly all of academic medicine, providing an unparalleled forum for presenting and discussing new findings. This was possible because academic medicine was far smaller than it is today. In 1960, the number of faculty members in the largest departments of medicine averaged well under 100, sometimes under 20, and the NIH provided about $\$ 200$ million in research grants annually - compared with over $\$ 20$ billion today. Successful physician-scientists today, such as those inducted into the ASCI, must compete with a far larger and more advanced group 